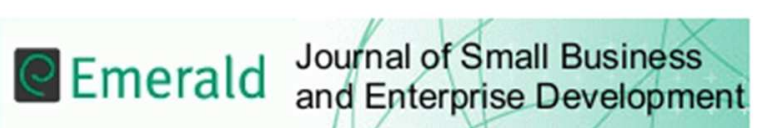

\title{
The use of internships to foster employability, enterprise and entrepreneurship in the IT sector
}

\begin{tabular}{|r|l|}
\hline Journal: & Journal of Small Business and Enterprise Development \\
\hline Manuscript ID: & JSBED-09-2014-0150 \\
\hline Manuscript Type: & Research Paper \\
\hline Keywords: & IT, internships, employability, entrepreneurship, enterprise \\
\hline \multicolumn{2}{|l}{} \\
\end{tabular}

SCHOLARONE

Manuscripts 
The use of internships to foster employability, enterprise and entrepreneurship in the IT sector

\section{Introduction}

Throughout Higher Education (HE) there is widespread acknowledgement that discipline-specific education is only a part of the responsibility institutions have in terms of delivery to students (e.g., Galloway and Brown, 2002). Additional components sought by employers in a competitive economy, and therefore by students who seek to gain employment after completion of studies, are employability and enterprise (Richardson and Hynes, 2008). As Sewell and Dacre Pool (2010) point out though, what is sought from employability and enterprise in graduates is not clear as the terms themselves are opaque and overlap considerably with each other, and with other concepts such as entrepreneurship, tacit skills and generic skills. There is little doubt though that all of these involve applied competencies that can be related to the world of work. As such, there is much rhetoric about the usefulness of workplace experience, based on the now well-established identification of experiential learning as the most effective means by which (particularly applied) skills are developed (Laurillard, 1993; Miller, 2002). In industries such as IT, a capable, creative and enterprising personnel base are said to be critical to organisational and sectoral development since these foster the potential for innovation and opportunity (Ratcliffe, 2009). For these reasons, and their potential in terms of economic development and national competitiveness in global industries, governments also are keen to encourage, and often support, work placements for students to improve employability and enterprise in technology sectors (e.g., BIS, 2011 in the UK).

The current paper reports a study of the usefulness of work placements for IT students and for employers in the IT sector in the UK. Within a qualitative methodological framework, using both surveys and interviews, the study presents findings about how placements are perceived from students' perspectives and from the perspectives of employers. The paper commences with a review of the literature on employment in the IT industry, followed by a discussion of employability, enterprise and entrepreneurship and their role in the IT sector. Following an explanation of the methodology used for the empirical study, findings relating to three research questions are presented. The paper concludes with a discussion on implications for 
employability, enterprise and entrepreneurship as they relate to IT educators, internship providers and the IT sector.

\section{Employment in the UK IT Industry}

Griffiths and Moore (2010) report that the UK IT industry is predicted to continue to grow. Similar claims of the particular robustness of the IT sector are made by industry and professional IT bodies; the UK IT industry body, e-skills, claims that the sector is better equipped to prevail and continue to grow and to provide high quality employment, even in recession, relative to other industries (Ratcliffe, 2009). Conversely, Bergvall-Kareborn and Howcroft (2011) claim that the value and employment potential of the IT industry is hyperbole. At the same time, there is some evidence that the landscape for the IT industry is changing; in the UK specifically, Marks and Huzzard (2010) find a reduction in foreign direct investment (FDI) of global players and a corresponding increase in small independent firms. In this new context, post FDI withdrawal, they find also lower amounts of inter-firm migration amongst employees and increased contract work. Bergvall-Kareborn and Howcroft (2011) concur, adding that while it prevails as a major global industry, the IT sector is increasingly characterised by short-term contracts and outsourcing. Baldry, et al. (2007) divide careers in the IT industry into those that are 'organisational' (i.e., within organisations) and 'horizontal-boundaryless' (those with a more portfolio characterisation, including periods of self-employment). These conditions comprise a precarious employment environment for the IT specialist whose career is increasingly likely to require that they work as what Bergvall-Kareborn and Howcroft $(2011, \mathrm{p} 3)$ call "self-employed employees" or "entreployees".

If contract work and self-employment are increasingly the norm, those working in the IT industry, including new entrants, are likely to require the experience, skills and networks to drive such a career. Therein lies a strong rationale for the development of non-technical skills in the IT industry: if we are to 'grow our own' in order that national sectors can innovate and compete in a global industry, and if we are to expect that a proportion of the IT workforce will continue to and increasingly comprise individuals who must drive their own careers through contracts and periods of selfemployment, we have to make available to IT students the opportunity to develop 
commercial and customer-facing skills in addition to technical abilities. This has clear implications for universities and other educators of IT professionals.

\section{Employability, enterprise, entrepreneurship}

Bridges (1994) notes that employability is hard to quantify. Despite this, various attempts have been made: Moreland (2006, p7) claims it comprises "a set of skills, knowledge and personal attributes that make an individual more likely to secure and be successful in their chosen occupation to the benefit of themselves, the workforce, the community and the economy" (also Dacre Pool and Sewell, 2007). The inferred skills include, according to Sewell and Dacre Pool (2010, p91-2), creativity, adaptability, independent working, working in a team, ability to manage others, communication skills, time management, ability to use new technologies, and commercial awareness. These can be roughly split into explicit skills, such as those involving technology, and tacit skills, such as communication and ability to work effectively in a team.

Enterprise is similarly hard to define, though again, various attempts are observable: Rae (2007, p610) defines it as "the skills, knowledge and attributes needed to apply creative ideas and innovations to practical situations". He includes almost all of the skills identified as referring to employability, such as creativity and independence, but includes others also, such as identifying opportunities and leadership. Rae (ibid) notes the similarity between enterprise skills and employability skills and concedes that they are highly overlapping; indeed, he advocates the use of enterprise teaching in universities as a means of developing employability skills. While agreeing with this, Sewell and Dacre Pool (2010, p.91) argue that the further concept of 'entrepreneurship' is distinct: they refer to it as involving enterprise or employability "but also something extra", namely "the ability to generate creative ideas, take risks in implementing them and be motivated to get them off the ground". In this way, in line with classic Knightian approaches to entrepreneurship (Knight, 1921), Sewell and Dacre Pool note risk as a fundamental component of entrepreneurship. Risk-taking, they claim, is not a quality attractive to employers; the idea that an individual may take risks with their capital and resources is unappealing. However, the entrepreneurship literature consistently cites affordance of behaviours associated with entrepreneurship amongst employees, including risk-taking, as one of the components 
that distinguishes growth-oriented and high-performing firms from others (e.g., Miller, 1983; Lumpkin and Dess, 1996). Moreover, it leads us to a further complicating and overlapping concept, intrapreneurship.

Antoncic and Hisrich (2003, p7) define intrapreneurship as "entrepreneurship in existing organisations". Within organisations entrepreneurship is associated with risk, innovation, proactivity (Miller, 1983), competitiveness and autonomy (Lumpkin and Dess, 1996), and has long been reported as a feature of high performing firms (e.g., Robertson and Collins, 2003). This being the case, we are led, full circle, to the idea that what innovation-driven industries, such as IT, require in order to develop is innovation and entrepreneurial growth within existing organisations, as well as the creation of new organisations and organisational forms. In order for a firm to achieve entrepreneurship it must have within its human resources people with the skills and abilities to act entrepreneurially (Wicklund and Shepherd, 2005). Thus, if employability and enterprise already overlap, then these also overlap with the concepts of entrepreneurship and intrapreneurship.

Following Nabi and Holden (2008), Sewell and Dacre Pool (2010) propose a continuum in terms of skills and attributes ranging from employability skills through enterprise skills to entrepreneurship. There is no reason to assume that one's place on this skills-continuum is static; the aim of education is to develop skills and those associated with Sewell and Dacre Pool's employability to entrepreneurship continuum are no different from any other kind of skills in this respect. Certainly, studies of the impact of enterprise and entrepreneurship education, such as Galloway and Brown, (2002) have reported skills development; in effect movement along Sewell and Dacre Pool's hypothesised continuum.

For students following a degree programme including IT and/or Computer Science, we might assume that explicit skills such as technology skills are included in curricula. For those engaged in programmes that include Business Studies, explicit skills taught might also include Finance or Management skills. The extent to which tacit skills, such as creativity and communication, may be developed during degree study is likely to vary by university however, depending on how highly the dissemination of employability skills are prioritised and the extent to which faculty 
practice includes these in their curricular and non-curricular delivery. Certainly, in the UK, universities are encouraged by government to include employability as an essential component of programmes, in particular including the application of skills in real-life contexts, and as a result many UK universities have put employability at the top of their agendas (BIS, 2011). However, university curricula can only go so far in terms of skills development, be that the application of explicit skills or the development of tacit skills. Fugate, et al. (2004) claim that experience and in-work learning will develop skills further.

\section{The role and value of student internships in the IT sector}

Providing IT students with placements is argued to benefit the IT sector in three ways. First, it affords development of business and commercial skills, or employability, amongst participants. Second, it can expose participants to an entrepreneurial environment in which they may become better equipped to consider entrepreneurship or at least have appropriate skills development to afford them effectiveness in periods of self-employment. Lastly, it provides for firms and the sector as a whole, a new generation of highly technically skilled knowledge workers with practical market experience. The hypotheses for each of these perspectives is detailed below.

\section{Employability}

Fugate et al. (2004) contend that technical skills alone are no longer enough for graduates entering the IT industry. Richardson and Hynes (2008) note the contribution placements can make to the employability of IT graduates; they claim that this has become so important that it is increasingly likely that those who have "strong technical abilities but little practical experience are losing out on potential jobs" (p190). At the same time, entry level employment in the IT sector in Western countries has reduced as a result of 'offshoring' - the movement of many 'first destination' jobs in support or basic programming abroad to countries such as India, where there is a cheaper supply of IT graduates with strong technical skills (Ratcliffe, 2009). The implication for UK IT graduates is a reduction in entry level long term contracts leading to a highly competitive (first) employment market. The need for employability skills that can be used to market oneself to, and perform in, firms has thus never been greater. 
In response to these assertions, the paper seeks to investigate Research Question 1: Do work placements develop useful employability skills that will better prepare students for the IT workplace?

\section{Entrepreneurship}

Following on from this, exposure to entrepreneurship education for students of technical subjects is advocated in the entrepreneurship literature (e.g., Keogh and Galloway, 2004), including practical learning through placements (Richardson and Hynes, 2008). The rationale for this is two-fold. First, as noted earlier in this paper, structural change in the IT sector has redefined how employment is managed for many, whereby responsibility for employment and professional development increasingly rests with individuals, leading to a subsequent increase in portfolio careers. While this has been reported extensively in the employment literature in recent years (e.g., Baldry, et al. 2007; Marks and Huzzard, 2010; Bergvall-Kareborn and Howcroft, 2011), it is also beginning to emerge in the entrepreneurship literature: in their study of the IT sector, Robert, et al. (2009, p 1) find a "surprising number of necessity entrepreneurs" (necessity being defined as self employment or business creation in the absence of suitable employment alternatives). Thus, placement experience in organisations is important as in order to sell oneself as a project contractor or self-employed, one must be able to draw upon real-world experience of both technical and commercial aspects of the industry to appear credible.

The second issue in terms of entrepreneurship is that placements can afford students the skills and training required for opportunity identification and pursuit within their technical specialism. Placements can enhance this by providing experiences of working in a commercial organisation and being exposed to the IT specialism in a market context, from which the ability to spot and pursue opportunities may develop. Potentially, at some point in an IT career, this may spawn the critical innovative new firms from which sector growth and employment may develop.

From the perspective of the individual, entrepreneurship, whether necessity- or opportunity-driven, creates a reasonable alternative to organisational employment. Thus Research Question 2 is generated: Do work placements improve students' abilities and attitudes to self employment and business creation in the IT sector? 


\section{Industrial Competitiveness}

In their study of the IT sector in Canada, Lucas, et al. (2009) compare the innovativeness and success of different IT clusters. They conclude that cluster success (in terms of innovation, growth and market share for firms) is best achieved within what they call a 'thick' environment - one where new and established organisations of different sizes and competencies coexist, along with institutional and support organisations, and research organisations including universities. The universities in particular serve not only as sources of innovation through knowledge exchange activities, but also as sources of new labour. Of this latter, they claim:

"the movement of students back and forth to industry through coop placements, as well as permanent hiring upon graduation, all serve as conduits of knowledge that keep firms at the leading edge of innovations and keep universities relevant to local industry" (Lucas, et al. 2009, p200).

Thus, along with evidence that placements can enhance IT graduates' chances of and preparation for employment, and even entrepreneurship, there is a strong argument that placements are highly valuable to industry also. The reasoning here is that placement experience can develop technical specialists for the commercial environment, and these practically experienced students will, in time, comprise for employers a recruitment pool better equipped to contribute value to organisations through the dissemination of technical knowledge, market and commercial understanding, and innovative ideas (McQuaid, 2002). The sector as a whole is enhanced in the same way, as firms continue to innovate and compete, and as opportunities to create new products and services, and new organisations, emerge and are acted upon by those with the requisite skills and ambitions to do so. From these arguments, Research Question 3 is generated: What are the perceived benefits of student internships to the IT industry?

\section{Methodology}

To investigate the three research questions identified, the paper provides a qualitative analysis of data produced to examine the practice and effectiveness of a student internship scheme provided by e-skills, the UK industry body for the IT sector. 
Qualitative analysis was considered most appropriate for the current study because it allows for results that reflect the positions and viewpoints of those being studied (Bryman, 1988) and includes therefore that which cannot be quantified or where being quantified does not provide any meaningful insight (Cassell and Symon, 1994). While it can be more difficult to generalise results with qualitative methods than in studies where quantitative methods have been used, Stake $(1995$, p.40) claims that through qualitative research we gain vicarious "experiential understanding" of a subject. The uniqueness of the experiences of those being studied in social science research is where a depth of understanding can be achieved, through analysis of commonality and divergence of human or social (or business) experience. Since the current paper aims to provide information and understanding of the value and experience of internships from the perspectives both of interns and of employers, qualitative data gathering is thus critical as it may afford an understanding of the perceptions and realities of the agents involved, and can link these to extant knowledge about the environment in which they exist.

\section{The Study}

E-skills, developed in 2010 a student placement programme, involving a substantial and growing number of UK universities, from which students of Computing, IT, Business and other disciplines have been placed in an organisation. These organisations include large firms such as IBM and $\mathrm{P} \& \mathrm{G}$, which typically take several students at a time, to smaller and newer organisations that may take only one student. Organisations range from specialist IT firms to non-IT organisations in the private, public and third sectors with an IT department or IT support function. All placements are paid and usually last one year (though shorter term internships are also available). Placements are available only to current students during their degree programmes. The focus of each placement is based on the specialism required by the organisation, and as such they provide both technical skills practice and development, as well as 'employability' skills development. E-skills (2010) summarise that the value of the internships scheme is to afford students "a rich blend of business, interpersonal and technical skills".

During September 2011, using data provided by e-skills, the authors conducted a survey of 100 students who have completed a placement and 120 employers who have 
provided at least one during the period 2010-2011. Forty-six responses to the interns' survey were obtained; 57 to the employers' survey. Both the employers' and interns' surveys were designed in such a way as to facilitate as much qualitative data as is reasonably possible with such an instrument. Respondents were invited to comment at length on their opinions and experiences of various pertinent issues.

Following the surveys, one to one telephone or in-person interviews were conducted in order to afford a deeper understanding of the role and value of the e-skills internships from both interns' and employers' perspectives. Five representatives from organisations that had provided an internship and six participants who had completed one agreed to be interviewed. For each, an interview guide was used to encourage free conversation about the topic and related emergent issues. Summaries of the interview participants are given in Tables 1 and 2. As per appropriate practice in interviewbased research, all conversations were recorded and transcribed verbatim. Following Miles and Huberman (1994), analysis was conducted in the first instance by each of the three researchers individually, and emerging themes were identified by consensus.

Table 1 here

Table 2 here

\section{Findings}

RQ1. Do work placements develop useful employability skills that will better prepare students for the IT workplace?

\section{Figure 1 here}

The data presented in Figure 1 is included to provide a general context to the following qualitative results. The figure shows responses from interns about whether skills have been developed by the placement experience and by the university experience. It also shows responses from employers about whether placements develop specific skills. Figure 1 illustrates that students perceive that both their internship and their university studies have contributed to their skills development, and that while this is marked for explicit technical skills, it is also particularly pertinent for the more tacit skills such as communications and team-working. 
Similarly, Figure 1 shows that employers, by and large, are consistent in their reporting of perceptions of skills developed by internships. Of course these data are descriptive only and statistical significance cannot be determined. However, the overall inference about skills often categorised as soft, transferrable, or relating to employability, such as communication, is that in-practice development is perceived as beneficial. This is supported by interview data:

Its about understanding how a business functions, the demands, the kind of agreements that have to be met, certainly meeting people, learning about diversity, so working with people from all around the world, how to interact in online meetings and then face to face meetings (intern interview 1).

The number one is definitely communication. Aside from that, being able to work in a team and being outgoing and that type of thing. All those kind of soft skills, those are the ones that are most improved (intern interview 2).

You learn how to be with a customer, how you be in a relationship with them, how to engage them (intern interview 3 ).

The development of explicit technical skills in real contexts was cited as another valuable function of internships by both interns and employers. For example, comments in the surveys such as the following were common:

working in a real project allowed me to put skills from my degree into practice (survey intern 1D4).

"I transferred uni-taught skills and techniques to real life business"(survey intern 1D20).

They always seem to say that they learnt more with us in one year than in the first two years of their degree course (survey employer, 1D51).

Findings from the interviews with both interns and employers corroborate these. For example, Employer B claims the value of the internships are that they afford the 
ability to recognise the relevance of what they are learning in the classroom and how it relates to the commercial world. Similarly, Intern Interviewees 3 and 4 identified that they developed competence in programming languages that had not been taught in university, thereby adding to their technical skills base.

So the value of internships appear to be perceived to be about both tacit and explicit skills development; technical, market/workplace, and transferable. As Intern Interviewee 1 puts it: its about the technical know-how as well as how the business works.

Less often identified as valuable for skills development was the role of universities. Despite reportage in Figure 1, the qualitative data indicates some perceptions of the limited contribution the universities may be making to skills development. This is particularly pertinent in terms of employability skills. For example, Intern Interviewee 4 claimed:

I don't think I learned anything about work really. Its theoretical stuff, which is nice to know, but it doesn't have much of an impact on my day to day work... lecturers, you know, don't have much real life experience and are not overly useful.

From the employers' perspectives, there was support for this. For example, when asked how prepared universities make students for work in the IT sector, employer interviewees' responses include: it was quite shocking that people...are quite incapable. I'm not overly impressed (A); I don't think they are prepared (B); its amazing how ill-prepared some graduates are (D). Employer E elaborates:

I don't think they're thinking about what employers need. I mean they're thinking about, you know, 'I'm a maths lecturer, this is what we do as mathematicians' not 'what do we need for the $21^{\text {st }}$ century'... They need to have an understanding of the world of work.

The application of employability skills and those required to operate in a working environment emerged as the main deficiencies. Even those environments that are not commercial are regarded as customer oriented as the IT function in many 
organisations is to service staff or project needs. Customer-facing skills and skills related to these, especially confidence and communication, were therefore high on the agendas of many participants in the research, and they were cited regularly as those that were developed by internships. One survey respondent summarises:

They have improved in all areas and most considerably in their communication and customer service skills and their confidence has been increased (1D28) .

Improvements in both explicit and tacit skills has, according to all responses to the interns' and employers' surveys and the interviewees, improved students' employability. In fact, comments made by employers relating to interviews for graduate positions bear this out:

Internships are actually in this day and age vitally important for employability and I've commented to other staff that when you interview you do actually notice a difference in the two...the other people on the panel were gobsmacked at the difference (employer interview D).

There is a distinct difference in the performance at interview between graduates that have completed a placement year compared to those that have not (survey employer 1D13).

I think that I would be very reluctant to hire a person who has come out of university without an internship. We would either hire a person who has done an internship or who has built up some experience in proper work basically (employer interview A).

Similarly, all six interns interviewed claimed that their internship had enhanced their employability; indeed, Interviewees 1 and 2 mentioned that their internships had made a contribution to successfully securing graduate employment, and Interviewees 4 and 5 were re-employed as graduates by the organisations in which they had done their internships. Further support for this includes the interview statements:

I think the main benefit really was that when applying and having interviews ... and on your $C V$ and cover letter having actually other things to write about. Everybody 
applying is going to have, you know, 'I did my degree', 'I got good marks' ... then like if you've actually been to a place for a year you can actually say, 'well I also improved my communication skills and there were tough situations that I had to deal with' (intern interview 2).

I'd done plenty of technical things at work [internship] which were of interest to some companies (intern interview 4).

Thus, one of the most commonly cited benefit of placements concerned the opportunity to experience the world of work and the personal development required for that. Employer interviewee B summarises:

I think they all grow up... They all come in quite young and naïve about things. I think its real exposure to what working in an organisation is like and I think it helps them work out where they ought to go with their future careers. Sometimes they come into this job thinking this is great and sometimes they do leave thinking this is not for me.

In fact, this idea that placements can identify for students that they are ill-suited to a specific IT career was mentioned surprisingly frequently by both interns and employers. As an outcome, this is no less impactful to an individual than skills development, as pursuing a career can take considerable resources and time. The usefulness of internships in informing students about what they are and are not suited to is highly valuable for a group who start working life with unprecedented levels of debt in a volatile employment market.

RQ2: Do work placements improve students' abilities and attitudes to self employment and business creation in the IT sector.

Results relating to the effects of internships on students' attitudes to and ambitions for self employment and business creation were limited. While, as reported above, employability skills were seen as vital, much less emphasis was placed by both students and employers on entrepreneurship and enterprise skills. In the interns' survey only eight of the 46 respondents had received any entrepreneurship education as part of their degree study, and as noted in Figure 1, a relatively few identified that 
entrepreneurial skills were developed at university or in internships. Similarly, in the employers' survey, only seven of the 57 respondents claimed that entrepreneurial skills were developed (12\%). Admittedly, relatively few of the employers who responded to the survey claimed to be owner-managers, and as such they may not perceive their role to be one where entrepreneurship, as an independent form of employment, might be encouraged. The only one owner-manager survey respondent did claim that internships ignite the entrepreneurial spirit when they see others starting businesses and making them successful (survey employer, 1D11).

Despite this though, only two respondents to the intern's survey identified that they were interested in starting a business, and of these one stated: I am interested in starting my own business, but I do not believe that I have the expertise and knowledge required to succeed at this stage in my life (survey intern 4C20). Little can be extrapolated from this: it may be that this respondent requires further industrial or commercial experience before venturing on his own, or it may reflect a lack of entrepreneurial skills and attitude development throughout the educational experience. Either way, it is the rareness of responses that acknowledge entrepreneurship as an employment or career possibility that is most concerning. This is particularly pertinent insofar as one of the intern interviewees is, in fact, now employed on a contractual basis to the firm in which he did his internship (see Table 2), but he does not consider himself to be self-employed. Similarly, in the interns' survey data one respondent identifies that my experience of work has been built through working for myself, a small organisation and also a multinational corporate (survey intern 3C9). With an increasing amount of outsourcing of IT work to contractors, and an increased likelihood that entrants to the IT sector will find themselves self-employed at some stage in their careers (like intern interviewee 5 and survey intern 3C9), we would expect to find more acknowledgement of the importance of development of skills to do this, and indeed, more evidence of acknowledgement of self-employment as an employment option amongst interns and employers. In fact, there is little evidence of either in the data, except for some rare mentions of the need to establish contacts and networks in the industry should contract work be necessitated.

$R Q$ 3: What are the perceived benefits of student internships to the IT industry? 
Results to RQ3 were revealing in a number of ways. The common assumption that interns comprise a source of cheap expertise does appear to be true. In the employers' survey 18 of the 57 respondents (32\%) claimed that internships were a good source of labour. However, two other commonly cited reasons for employers to engage with the placements scheme were to access good potential recruits for graduate jobs and to provide up to date and enthusiastic input to organisations.

In terms of using internships as a graduate recruitment strategy, 17 of the 57 survey responses $(30 \%)$ confirm this. Comments in the employers' survey include, for example:

We have the ability to assess future potential employees on a year-long interview (survey employer, 1D1)

It gives us a no-risk look at individuals with a view to the graduate positions that may become available (survey employer, 1D14).

Interview data from interns and employers supports this further:

we use placements as an extended interview (employer interview A)

all of them have gone on to get jobs with us, its like growing our own (employer interview E)

the whole company's pretty much built up of old placement students....after their final year, if they're alright, often they'll get a job (intern interview 4)

there are two process for applying to XXX. One is an internal process... and what that is is they reach out to the existing industrial placement students (intern interview 6).

In fact, all of the employers interviewed have recruited to graduate positions direct from internships. Using internships as a recruitment mechanism is a saving in time and resources in terms of recruitment spend, and is especially valuable for graduate recruitment, whereby lack of experience in industry equates to higher risk for 
employers. Employers are able to specify the skills developed, tailor them to specific organisational culture or requirements, and select those recruits who develop and perform best in internship.

Organisations benefit from internships in other ways also. The contributions interns made, as noted by employers, include new and fresh ideas (survey employer, 1D1), bright new talent (survey employer, 1D5), enthusiasm and up to date techniques (survey employer, 1D30). Interview data includes similarly positive statements. For example, Employer B claims they do give you a fresh pair of eyes to look at things...they do just kind of bring that breath of fresh air back into the organisation. Employer $\mathrm{C}$ notes that the technical expertise can be valuable also: The kids of today, you know, are up more with the latest technologies and the brightest ideas.

So the data suggests that the contribution interns can make to organisations is twofold, including enthusiasm and new ways of looking at things, and up to date technological expertise. One survey respondent summarises:

We get a shot of creativity and fresh thinking. Interns tend to strip away the 'we must do this because we've done it that way for 10 years' thinking and say 'well if you do this its much simpler and gets the job done'. Some of our interns have been great at perfecting our inductions for new staff while others have introduced technology to areas where it was previously unheard of (survey employer, 1D44).

The contribution of interns to organisations can be extrapolated to infer contribution to the IT industry generally. New ideas and alternative ways of doing things evoke notions of creativity and enterprise. Specialist, cutting edge knowledge of technologies in a dynamic and fast-paced sector such as IT is required for organisational and industrial competitiveness. The training and experience provided by internships in the IT sector, combined with university-taught technological skills and knowledge, does seem to make for a valuable contribution.

\section{Discussion}

The study finds that in terms of the development of employability skills, student placements in the IT sector do make a strong contribution. Further, it supports the 
assertion of Richardson and Hynes (2008) that internships are becoming increasingly important to the employability and employment prospects of IT graduates. Comments from employers about how prepared IT students are for work in the IT industry are concerning, however. Employers, while recognising the contribution interns can make to organisations in terms of skills and expertise, are less impressed with prior knowledge about and application of skills in a commercial or otherwise real-world context. The inference for university IT departments is that there could be much more done in terms of preparing IT and Computing students for the types of employment they will be required to engage with, especially in terms of developing the more tacit employability skills required by commercial and support organisations.

In terms of entrepreneurship, results are even more concerning. The study corroborates the extant literature (e.g., Baldry, et al., 2007; Robert, et al., 2009) by finding evidence that new entrants to the IT sector are likely to spend periods of their careers as self-employed. Evidence of acknowledgement of the implications of this, particularly in terms of the need to develop skills and strategies for operating as selfemployed in the IT environment, seems to be largely absent though. The employers, who by and large do not represent owner managers, do appear to be contributing much value to students in terms of developing employability skills. While these skills are those which are of most benefit to employers, they do appear to comprise consistency and overlap with skills associated with enterprise in that enterprising and customer-based orientation appear to be amongst that fostered. What the data does not suggest, is that entrepreneurship, as a positive career choice or opportunity, is acknowledged either by interns in the context of their futures, or by employers in the context of industry development. While it is not the business of established organisations to promote new firms (which may comprise competition), there is implied a deficiency in expectation management of students in universities. First, students appear to be neither aware of the likelihood of, nor equipped for, selfemployment in the form of contractual work, and second, there is no evidence in the current study that there is any perception that the IT industry might provide entrepreneurial opportunities other than as a set of competencies and attitudes to be applied within existing organisations.

\section{Implications and Conclusions}


Results from the current study suggest that, as per the extant literature (e.g., McQuaid, 2002), new graduates have much to contribute to the IT sector. They also support the assertion that as a means of developing people, placements make a valuable contribution to preparations for employment for IT students. As a result, the value of internships and a rationale for their continued availability through programmes such as that provided by e-skills in the UK is supported.

At the same time, the difference observed by employers in preparedness and employability between those who have undertaken an internship and those who have not exposes the implication that not enough is currently being done in universities to prepare IT students for the realities of work in the sector. If universities have an obligation to prepare students for work, the evidence here suggests that deficiencies in university delivery are mitigated to some extent by internships. However, worryingly, there is an absence of evidence that there is any acknowledgement that contractual work has become an increasingly common destination, or that entrepreneurship within the sector has a vital role to play in terms of innovation and competitiveness. Since fewer than twenty per cent of the sample of interns had received entrepreneurship education at university, the suggestion is that more is required at the university level to promote awareness, attitudes and skills associated with the enterprise and entrepreneurship ends of the employability skills continuum. This is made more pertinent by the suggestion that internships are not likely to mitigate a lack of entrepreneurship education in university as it is not the business of existing firms to encourage or support entrepreneurial development in individual interns.

The current study is cross sectional in nature, and based on responses from a limited number of intern and employer informants. The suggestions emerging from the research must be treated with some caution therefore. Further research might investigate at a different time, or with a different IT internship scheme, whether results are consistent. It would also be interesting to compare results from the current study with results from studies of internships in different countries and in different technical or vocational disciplines. A longitudinal study following students from placements, through first entry and into established careers would also be enlightening in terms of reflecting on how and where employability (and enterprise) skills are most 
developed, and indeed, to investigate the experiences of both employment and selfemployment in terms of the deployment of these skills.

\section{References}

Antoncic, B. \& Hisrich, R.D. (2003) "Clarifying the intrapreneurship concept", Journal of Small Business and Enterprise Development, Vol.10 No.1, pp.7-24.

Baldry, C., Bain, P., Taylor, P., Hyman, J., Scholarios, D., Marks, A., Watson, A., Gilbert, K., Gall, G., and Bunzel, D. (2007) The meaning of work in the new economy, Palgrave, London.

Bergvall-Kareborn, B. \& Howcroft, D. (2011) "Crowdsourcing and ICT work: A study of Apple and Google mobile application developers" available at http://www.crowdsourcing.org/document/crowdsourcing-and-ict-work-a-study-ofapple-and-google-mobile-phone-application-developers/4274

BIS (2011) Students at the Heart of the System, UK Government white paper, available at http://discuss.bis.gov.uk/hereform/white-paper/

Bridges, W. (1994) Job Shift: How to Prosper in a Workplace Without Jobs, AddisonWesley, Reading, MA.

Bryman, A.(1988) Quantity and Quality in Research London: Unwin Hyman.

Cassell, C. and Symon, C. (1994) "Qualitative Research in Work Contexts" in Cassell and Symon (eds) Qualitative Methods in Organizational Research: A Practical Guide pp.1-13 London: Sage Publications.

Dacre Pool, L. and Sewell, P. (2007), "The key to employability: developing a practical model of graduate employability", Education+Training, Vol. 49 No. 4, pp. 277-89.

e-skills (2010) e-skills Internship - The Professional Placement, e-kills, London, available online at http://www.e-skills.com/Com/internship\%20documents/eskillsInternship_brochure.pdf

Fugate, M., Kinicki, A. J. and Ashforth, B. E. (2004) "Employability: A psycho-social construct, its dimensions, and applications", Journal of Vocational Behavior Vol.65, pp. 14-38.

Galloway, L. \& Brown, W. (2002) "Entrepreneurship education at universities as a driver in the creation of high growth firms", Education and Training, Vol.44 No.8/9, pp.398-405 
Griffiths, M. and Moore, K. (2010) "Disappearing women: a study of women who left the UK ICT sector", Journal of Technology Management \& Innovation Vol.5 No.1, pp. 95-107.

Keogh, W. \& Galloway, L. (2004) "Teaching enterprise in vocational disciplines: reflecting on positive experience", Management Decision, Vol.42 No.3/4, pp.531541.

Knight, F. 1921. Risk, Uncertainty and Profit, Houghton Mifflin, New York.

Laurillard, D. (1993) Rethinking University Teaching: A framework for the effective use of educational technology, Routledge, London.

Lucas, M., Sands, A. \& Wolfe, D.A. (2009) "Regional clusters in a global industry: ICT clusters in Canada", European Planning Studies, Vol.17 No.2, pp. 189-209.

Lumpkin, G.T. and Dess, G.G. (1996) "Clarifying the entrepreneurial orientation construct and linking it to performance", Academy of Management Review, Vol.21 No.1, pp.135-172.

Marks, A. and Huzzard, T. (2010) "Employability and the ICT worker: a study of employees in Scottish small businesses", New Technology, Work and Employment, Vol.25 No.2, pp. 167-181.

McQuaid, R. (2002) "Entrepreneurship and ICT industries: support from regional and local policies", Regional Studies, Vol.36 No.8, pp. 909-919

Miles, M. and Huberman, M. (1994) Qualitative Data Analysis: An Expanded Sourcebook, Sage Publications: Thousand Oaks.

Miller, D. (1983) "The correlates of entrepreneurship in three types of firms", Management Science, Vol.29, pp. 770-791.

Miller, P.H. (2002), Theories of Developmental Psychology, Worth, New York.

Moreland, N. (2006) Learning \& Employability: Entrepreneurship and higher education - an employability perspective, Enhancing Student Employability Coordination Team, The Higher Education Academy, York.

Nabi, G. \& Holden, R. (2008) "Graduate entrepreneurship: intentions, education and training”, Education + Training, Vol.50 No.7, pp. 545-551.

Rae, D. (2007) "Connecting enterprise and graduate employability", Education + Training, Vol.49 No.8/9, pp. 605-619.

Ratcliffe, M. (2009) Researching Graduate Employment in IT: A report on research conducted by Experian for the HEFCE supported Revitalise IT project, e-skills, London. 
Richardson, I. \& Hynes, B. (2008) "Entrepreneurship education: towards an industry sector approach", Education + Training, Vol.50 No.3, pp. 188-198.

Robert, F., Marques, P., Lasch, F. \& Le Roy, F. (2009) "Entrepreneurship in emerging high-tech industries: ICT entrepreneurs between experts and kamikazes", International Journal of Entrepreneurship and Small Business, Vol.7 No.3, pp. 258283.

Robertson, M and Collins, A. (2003) "Developing entrepreneurship in West Yorkshire: West Yorkshire universities’ partnership and Business Start-up @ Leeds Met" Education and Training, Vol.45 No.6, pp. 303-307.

Sewell, P. \& Dacre Pool, L. (2010) "Moving from conceptual ambiguity to operational clarity", Education + Training, Vol.52 No.1, pp. 89-94

Stake, R.E. (1995) The Art of Case Study Research, London: Sage Publications.

Wiklund, J. and Shepherd, D. (2005) "Entrepreneurial orientation and small business performance: a configurational approach", Journal of Business Venturing, Vol. 20, pp.71-91. 
Table 1: Summary of Employer Interviewees

\begin{tabular}{|l|l|l|l|}
\hline Interviewee & $\begin{array}{l}\text { Size and type of } \\
\text { organisation }\end{array}$ & $\begin{array}{l}\text { Number of IT interns } \\
\text { in UK in the last year }\end{array}$ & $\begin{array}{l}\text { Core Business IT or } \\
\text { not IT }\end{array}$ \\
\hline A & $\begin{array}{l}\text { Large international } \\
\text { firm }\end{array}$ & 1 & IT \\
\hline B & $\begin{array}{l}\text { Large international } \\
\text { firm }\end{array}$ & 7 & Not IT \\
\hline farge international & 20 & IT \\
\hline D & HE organisation & 3 & Not IT \\
\hline E & $\begin{array}{l}\text { Local public } \\
\text { organisation }\end{array}$ & 2 & Not IT \\
\hline
\end{tabular}

Table 2: Summary of Intern Interviewees

\begin{tabular}{|l|l|l|l|}
\hline \multirow{2}{*}{ Interviewee } & \multicolumn{2}{|c|}{ Internship Organisation } & \multirow{2}{*}{ Current Status } \\
\cline { 2 - 4 } & $\begin{array}{l}\text { Size and type of } \\
\text { organisation }\end{array}$ & $\begin{array}{l}\text { Core Business IT or } \\
\text { not IT }\end{array}$ & $\begin{array}{l}\text { Large international } \\
\text { firm Not IT } \\
1\end{array}$ \\
\hline 2 & $\begin{array}{l}\text { Large international } \\
\text { firm }\end{array}$ & Not IT & $\begin{array}{l}\text { Employed in IT dept as } \\
\text { graduate }\end{array}$ \\
\hline 3 & $\begin{array}{l}\text { Local public } \\
\text { organisation }\end{array}$ & Not IT & $\begin{array}{l}\text { Employed in medium } \\
\text { sized IT firm }\end{array}$ \\
\hline 4 & $\begin{array}{l}\text { Small private firm } \\
\text { job; not in IT }\end{array}$ \\
\hline 5 & $\begin{array}{l}\text { Large international } \\
\text { firm Not IT }\end{array}$ & $\begin{array}{l}\text { Graduate employment } \\
\text { with internship firm }\end{array}$ \\
\hline 6 & $\begin{array}{l}\text { Large international } \\
\text { firm }\end{array}$ & $\begin{array}{l}\text { Employed as an IT } \\
\text { contractor to internship } \\
\text { firm. }\end{array}$ \\
\hline
\end{tabular}


Figure 1: Use and Development of Skills

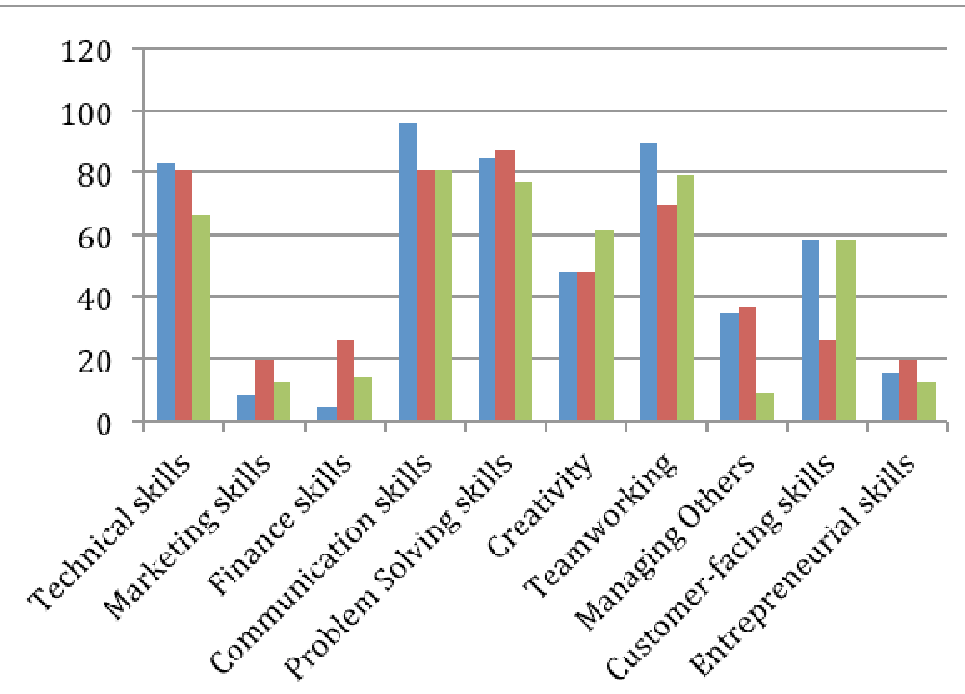

- Skills developed by internship (interns)

- Skills developed by university studies [interns]

Skills developed by internship (employers) 